\title{
A NOTE ON REGIONAL NONAGRICULTURAL EMPLOYMENT
}

\author{
Edward Nissan and Regina Caveny*
}

\section{Introduction}

In recent years, the popular press has given the impression that massive shifts in nonagricultural employment have occurred, predominantly from the industrial North to the Sunbelt. This note investigates the impact of these shifts upon regional employment patterns at various industry levels and specifically examines the hypothesis that industry employment has become more evenly distributed among regions.

Table 1 provides data on the major changes that took place between 1960 and 1980 for various industry divisions (construction; manufacturing; transportation and public utilities; wholesale and retail trade; finance, insurance and real estate; service and miscellaneous; and government) in the nine geographic census regions of the United States. Total U.S. employment for the 20-year period increased by 69.1 percent but the growth is unevenly distributed among the geographic areas. The Mountain region, with an increase of 132 percent, enjoyed the largest gain, followed by the West South Central region with 110 percent. The Middle Atlantic region lagged behind with a growth rate of only 25.5 percent. This diverse growth pattern is also evident in the comparison of specific industries. For instance, in manufacturing, the Mountain region's gain is 115 percent, while the Middle Atlantic's loss is approximately 14 percent. Similar variations may be observed in other industrial sectors.

Has the rapid growth of industries in regions of the South and West, coupled with diminishing activity in the Northeast and North Central regions had a homogenizing effect on employ-

* Professor of Economics, University of Southern Mississippi, and Instructor of Economics, University of Southern Mississippi. ment opportunities in the major industrial sectors? The hypothesis that nonagricultural employment patterns have become less differentiated as a result of the uneven growth rates between 1960 and 1980 is examined empirically in the note.

\section{Methodology}

Analysis of variance techniques were applied to data from the Statistical Abstract of the United States, selected at five-year intervals between 1960 and 1980. Typically, measurements or observations used in analysis of variances are gathered from experimental results such as in agricultural, biological, or marketing research. However, economic data which arise from nonexperimental activities may also be analyzed by means of analysis of variance methodology (Iverson and Norpoth, 1976 , p. 6). Two hypotheses are tested by means of a one-way classification model:

(1) For each industry sector, the nine geographic regions are tested for equality of means. The hypothesis of equality of means implies that employment opportunities are homogeneous in all regions for that particular industrial division. If the hypothesis is rejected, the implication is that at least one region differs substantially from the others.

(2) The second null hypothesis tested is that no changes occurred in the industry sector means during the period 1960-80. If this hypothesis can be rejected, the implication is that sectoral employment patterns for the country as a whole have changed.

The data used in the computations are shown in Table 2. Since the magnitude of employment in each region for each sector differs considerably, it was necessary to express the data in terms of a total per hundred observations. The computations necessary for the first hypothesis are undertaken by rows for each geographic region within industrial sectors, while the computations for the second 
Tablo 1

Rolative Nonagricultural Employment Change: 1960-1980 by Geographic Region and by Industry" Numbers in Thoseanda)

\begin{tabular}{|c|c|c|c|c|c|c|c|c|}
\hline Region & Total & Construction & Manufacturing & $\begin{array}{l}\text { Traneportation } \\
\text { and } \\
\text { Public Utilitios }\end{array}$ & $\begin{array}{c}\text { Wholesale } \\
\text { and } \\
\text { Retail Trade }\end{array}$ & $\begin{array}{l}\text { Pinance, } \\
\text { Insurance } \\
\text { \& Real Estate }\end{array}$ & $\begin{array}{c}\text { Service } \\
\text { and } \\
\text { Miscellnesous }\end{array}$ & Government \\
\hline \multicolumn{9}{|c|}{ Induetry 1960} \\
\hline United States & 52898 & 2172 & 16357 & $\overline{\operatorname{sen} 2}$ & 11642 & 2485 & 7302 & 8458 \\
\hline New England & 3697 & 163 & 1445 & 202 & 709 & 186 & 524 & 469 \\
\hline Middle Atlantic & 11914 & 524 & 4128 & 911 & 2325 & 726 & 1792 & 1508 \\
\hline East North Central & 11486 & 529 & 4460 & 786 & 2311 & 480 & 1420 & 1498 \\
\hline West North Central & 4155 & 238 & 996 & 375 & 1012 & 206 & 615 & 716 \\
\hline East South Central & 2739 & 145 & 840 & 182 & 568 & 109 & 394 & 503 \\
\hline West South Central & 4243 & 275 & 820 & 386 & 1047 & 194 & 745 & 777 \\
\hline Mountain & 1865 & 140 & 262 & 166 & 435 & 81 & 372 & 415 \\
\hline Pacific & 6298 & 389 & 1695 & 473 & 1392 & 309 & 888 & 1164 \\
\hline \multicolumn{9}{|c|}{ Induetry 1880} \\
\hline United States & 89456 & 4899 & 20500 & 5143 & 20886 & 5168 & 17901 & 16249 \\
\hline New England & 5474 & 184 & 1523 & 238 & 1167 & 329 & 1203 & 830 \\
\hline West North Central & 6850 & 306 & 1879 & 486 & 1709 & 373 & 1361 & 1286 \\
\hline South Atlantic & 14510 & 853 & 3042 & 810 & 3229 & 774 & 2731 & 3071 \\
\hline East South Central & 5041 & 250 & 1364 & 267 & 1074 & 221 & 823 & 1042 \\
\hline West South Central & 8912 & 664 & 1662 & 602 & 2214 & 499 & 1601 & 1670 \\
\hline Mountain & 4327 & 291 & 564 & 277 & 1055 & 242 & 964 & 934 \\
\hline Pacific & 13005 & 602 & 2560 & 742 & 3040 & 824 & 2793 & 2444 \\
\hline \multicolumn{9}{|c|}{ Percentage Change } \\
\hline United States & 69.1 & $\mathbf{5 8 . 7}$ & 24.8 & 31.8 & 76.1 & 108.0 & 145.2 & 82.1 \\
\hline New England & 48.1 & 12.9 & 5.4 & 17.8 & 64.6 & 76.9 & 129.6 & 77.0 \\
\hline Middle Atlantic & 25.5 & -3.1 & -13.7 & -2.6 & 34.8 & 40.2 & 82.9 & 70.2 \\
\hline East North Central & 45.7 & 22.9 & 5.7 & 7.8 & 62.9 & 81.3 & 119.9 & 84.7 \\
\hline West North Central & 64.9 & 28.6 & 38.5 & 16.3 & 68.9 & 81.1 & 121.3 & 79.6 \\
\hline South Atlantic & 103.3 & 87.1 & 49.9 & 60.7 & 113.7 & 135.3 & 170.1 & 128.0 \\
\hline East South Central & 84.0 & 72.4 & 62.4 & 46.7 & 89.1 & 102.8 & 108.9 & 107.2 \\
\hline West South Central & 110.0 & 141.5 & 102.7 & 56.0 & 111.5 & 157.2 & 114.9 & 114.9 \\
\hline Mountain & 132.0 & 107.9 & 115.3 & 66.9 & 142.5 & 198.8 & 159.1 & 125.1 \\
\hline Pacific & 106.5 & 54.8 & 51.0 & 56.9 & 118.4 & 166.7 & 214.5 & 111.8 \\
\hline
\end{tabular}

National totals differ from the sum of the state figures because some states have more recent benchmarks and because the stratification of in. dustries differs among states.

Source: U.S. Bureau of the Census, Statistical Abstract of the United States. (Washington, D.C.: U.S. Government Printing Office, various years).

analysis are by columns for the specified years within each industry sector.

In the analysis of variance technique, the hypothesis is stated in terms of equality of means. The significance test, however, is conducted in terms of the variances of the respective means. This approach is an extension of the testing procedure for the equality of two means. The proper test statistic for the null hypothesis is the F-distribution. The hypothesis of equal means will be rejected when the computed $F$-value is greater than $F_{1-\alpha, k-1, n-k}$ for a test whose significance level is $\alpha$. Here k denotes the number of means being considered and $\mathrm{n}$ is the total number of observations.

\section{Testing for Homogeneity of Employment in Different Regions}

With respect to the first hypothesis, which considers the question of whether or not various industrial employment opportunities differ from region to region, the computed F values ranged from 3.69 to 22.90. The proper critical values of $F$ are:

$$
F_{.95,8,36}=2.21
$$

or

$$
\mathbf{F}_{.99,8,36}=3.04 \text {. }
$$

The null hypothesis must be rejected in every case, since all computed F-ratios exceed the critical values for $\alpha=.05$ and $\alpha=.01$. Therefore, it must be concluded from the test results that employment opportunities in the various industrial sectors for the nine geographic regions of the United States are not homogeneous, despite the trends of the last two decades.

While overall regional homogeneity of employment does not appear to exist, it is possible that employment patterns in some industrial sectors do not vary between the dif- 
Table 2

Nonagricultural Employment per 100 employees by Geographic Region and Induetrial Diviaion 1960-1980 (Five-Year Intervals)

\begin{tabular}{|c|c|c|c|c|c|c|c|c|c|c|c|c|c|c|c|}
\hline \multirow[t]{2}{*}{ Recion } & \multicolumn{5}{|c|}{ Contrect Conetruction } & \multicolumn{5}{|c|}{ Manufacturing } & \multicolumn{5}{|c|}{$\begin{array}{l}\text { Transportation \& } \\
\text { Public Utilitios }\end{array}$} \\
\hline & 1960 & 1965 & 1970 & 1975 & 1980 & 1960 & 1965 & 1970 & 1975 & 1980 & 1960 & 1965 & 1970 & 1975 & 1980 \\
\hline $\begin{array}{l}\text { New England } \\
\text { Middle Atlantic } \\
\text { East North Central } \\
\text { West North Central } \\
\text { South Atlantic } \\
\text { East South Central } \\
\text { West South Central } \\
\text { Mountain } \\
\text { Pacific }\end{array}$ & $\begin{array}{l}4.4 \\
4.4 \\
4.6 \\
5.7 \\
6.3 \\
5.3 \\
6.5 \\
7.5 \\
6.2\end{array}$ & $\begin{array}{l}4.6 \\
4.2 \\
4.4 \\
5.4 \\
6.7 \\
5.8 \\
6.7 \\
6.3 \\
5.5\end{array}$ & $\begin{array}{l}4.5 \\
4.1 \\
4.0 \\
4.7 \\
6.1 \\
5.0 \\
6.0 \\
5.6 \\
4.5\end{array}$ & $\begin{array}{l}3.6 \\
3.5 \\
3.7 \\
4.4 \\
5.7 \\
5.1 \\
6.2 \\
5.9 \\
4.1\end{array}$ & $\begin{array}{l}3.4 \\
3.4 \\
3.9 \\
4.5 \\
5.9 \\
5.0 \\
7.5 \\
6.7 \\
4.6 \\
\end{array}$ & $\begin{array}{l}39.1 \\
34.7 \\
38.8 \\
24.0 \\
28.3 \\
30.7 \\
19.3 \\
14.0 \\
26.9\end{array}$ & \begin{tabular}{l|}
36.5 \\
32.8 \\
38.0 \\
23.4 \\
27.4 \\
31.5 \\
19.6 \\
13.3 \\
24.1
\end{tabular} & $\begin{array}{l}32.1 \\
29.5 \\
34.6 \\
22.9 \\
25.6 \\
32.1 \\
20.3 \\
13.7 \\
22.0\end{array}$ & $\begin{array}{l}27.9 \\
25.1 \\
30.4 \\
20.5 \\
22.0 \\
28.1 \\
18.4 \\
12.3 \\
19.7\end{array}$ & $\begin{array}{l}27.8 \\
23.8 \\
28.1 \\
20.1 \\
21.0 \\
27.1 \\
18.6 \\
13.0 \\
19.7\end{array}$ & $\begin{array}{l}\mathbf{5 . 5} \\
\mathbf{7 . 7} \\
\mathbf{6 . 9} \\
\mathbf{9 . 0} \\
\mathbf{7 . 0} \\
\mathbf{6 . 6} \\
\mathbf{9 . 1} \\
\mathbf{8 . 9} \\
\mathbf{7 . 5}\end{array}$ & $\begin{array}{l}5.0 \\
7.1 \\
6.1 \\
7.7 \\
6.3 \\
5.9 \\
7.9 \\
7.7 \\
6.8\end{array}$ & $\begin{array}{l}\mathbf{5 . 0} \\
6.7 \\
5.8 \\
7.1 \\
6.3 \\
5.5 \\
7.2 \\
6.8 \\
6.7\end{array}$ & $\begin{array}{l}4.6 \\
6.2 \\
5.4 \\
6.5 \\
5.8 \\
5.2 \\
6.7 \\
6.3 \\
6.1\end{array}$ & $\begin{array}{l}.8 \\
5.9 \\
5.1 \\
6.4 \\
5.6 \\
5.3 \\
6.8 \\
6.4 \\
5.7\end{array}$ \\
\hline
\end{tabular}

\begin{tabular}{|c|c|c|c|c|c|c|c|c|c|c|}
\hline \multirow[t]{2}{*}{ Region } & \multicolumn{5}{|c|}{ Wholesale Retail Trede } & \multicolumn{5}{|c|}{$\begin{array}{l}\text { Finance, Insurance } \\
\text { and Reel Betate }\end{array}$} \\
\hline & 1960 & 1965 & 1970 & 1975 & 1980 & 1960 & 1965 & 1970 & 1976 & 1880 \\
\hline New England & 19.2 & 19.3 & 20.5 & 21.6 & 21.3 & 5.0 & 5.1 & 5.5 & 5.9 & 6.0 \\
\hline Middle Atlantic & 19.5 & 19.7 & 19.9 & 20.7 & 21.0 & 6.1 & 6.0 & 6.4 & 6.7 & 6.8 \\
\hline East North Central & 20.1 & 19.7 & 20.6 & 21.8 & 22.5 & 4.2 & 4.3 & 4.4 & 4.7 & 5.2 \\
\hline West North Central & 24.3 & 23.8 & 23.7 & 24.6 & 24.9 & $\mathbf{5 . 0}$ & 5.0 & 5.0 & 5.1 & 5.4 \\
\hline South Atlantic & 21.0 & 20.6 & 20.8 & 21.6 & 22.2 & 4.6 & 4.7 & 4.8 & 5.4 & 5.3 \\
\hline East South Central & 20.7 & 19.6 & 19.2 & 20.4 & 21.3 & 4.0 & 4.0 & 4.0 & 4.3 & 4.4 \\
\hline West South Central & 24.7 & 23.7 & 23.0 & 23.8 & 24.8 & 4.6 & 4.9 & 5.0 & 5.5 & 5.6 \\
\hline Mountain & 23.3 & 22.8 & 22.7 & 23.4 & 24.4 & 4.3 & 4.7 & 4.7 & 5.1 & 5.6 \\
\hline Pacific & 22.1 & 22.1 & 22.2 & 22.8 & 23.4 & 4.9 & 5.4 & 5.4 & 5.7 & 6.3 \\
\hline
\end{tabular}

\begin{tabular}{|c|c|c|c|c|c|c|c|c|c|c|}
\hline \multirow[t]{2}{*}{ Region } & \multicolumn{2}{|c|}{ Service } & \multicolumn{3}{|c|}{ Miscelleneous } & \multicolumn{5}{|c|}{ Government } \\
\hline & 1960 & 1965 & 1970 & 1975 & 1980 & 1960 & 1965 & 1970 & 1975 & 1980 \\
\hline $\begin{array}{l}\text { New England } \\
\text { Middle Atlantic } \\
\text { East North Central } \\
\text { West North Central } \\
\text { South Atlantic } \\
\text { East South Central } \\
\text { West South Central } \\
\text { Mountain } \\
\text { Pacific }\end{array}$ & $\begin{array}{l}14.2 \\
15.0 \\
12.4 \\
14.8 \\
14.1 \\
14.4 \\
17.5 \\
19.8 \\
14.1\end{array}$ & $\begin{array}{l}16.0 \\
16.3 \\
13.6 \\
16.1 \\
14.9 \\
14.5 \\
18.4 \\
20.9 \\
16.2\end{array}$ & $\begin{array}{l}18.2 \\
18.7 \\
15.0 \\
17.0 \\
15.8 \\
14.8 \\
19.0 \\
22.1 \\
18.2\end{array}$ & $\begin{array}{l}20.3 \\
19.9 \\
17.4 \\
18.9 \\
18.1 \\
16.7 \\
19.9 \\
23.3 \\
20.1\end{array}$ & $\begin{array}{l}22.0 \\
21.9 \\
18.7 \\
19.9 \\
18.8 \\
16.3 \\
18.0 \\
22.3 \\
21.5\end{array}$ & $\begin{array}{l}12.6 \\
12.7 \\
13.0 \\
17.2 \\
18.7 \\
18.3 \\
18.3 \\
22.2 \\
18.3\end{array}$ & $\begin{array}{l}13.5 \\
13.9 \\
13.7 \\
18.6 \\
19.4 \\
18.7 \\
18.8 \\
24.3 \\
19.9\end{array}$ & $\begin{array}{l}14.2 \\
15.6 \\
15.6 \\
19.6 \\
20.6 \\
19.4 \\
19.5 \\
24.4 \\
21.0\end{array}$ & $\begin{array}{l}16.1 \\
17.9 \\
16.5 \\
19.9 \\
21.4 \\
20.2 \\
19.5 \\
23.7 \\
21.5\end{array}$ & $\begin{array}{l}15.2 \\
17.2 \\
16.5 \\
18.8 \\
21.2 \\
20.6 \\
18.7 \\
21.6 \\
18.8\end{array}$ \\
\hline
\end{tabular}

Source: U.S. Bureau of the Census, Statistical Abstract of the United States. (Washington, D.C.: U.S. Government Printing Office, various years).

ferent regions. This possibility may be examined by using a statistical test involving linear contrasts, a procedure which systematically examines all possible pairs of group means. There are several methods that might be employed for this purpose, but the one deemed appropriate is Tukey's Multiple Range procedure (Hawkins and Weber, 1980, p. 333).

For ease of presentation of the results, the geographic regions are coded as follows:
1. New England
6. East South Central
2. Middle Atlantic
7. West South Central
3. East North Central 8. Mountain
4. West North Central 9. Pacific
5. South Atlantic

Table 3 presents the various possible subsets obtained by Tukey's Multiple Range procedure at $\alpha=.05$. Regions listed as belonging to a common subset do not differ significantly in their means. However, regions not appearing in the same subset do have significantly different mean employment levels. For example, in the Contract Construction sector, Region 6 differs from Region 2, but it does not differ from Regions 1, 3, 4 and 9. Also, Region 5 differs from Regions 2, 1, 3 and 4, but it does not differ significantly from Regions 9 and 6. Although none of the sectors show homogeneous employment opportunities, it may be observed that two sectors, Service and Miscellaneous and Government, are much less diverse than the other sectors.

\section{Testing for Differences in Employment Over Time}

The second analysis examines the nature of employment patterns over time to determine if 
employment concentration in each industrial sector has experienced a significant change during the two decades, 1960-80. More specifically, the null hypothesis is that no changes occurred in the industry sector means during the period $1960-80$.

The statistical procedure adopted here is similar to the one used above. The results of the computed $F$ values range between 1.27 and 7.98. On comparing these values with the critical values of

$$
\text { or } \begin{aligned}
F_{.95,4,40} & =2.61, \\
F_{.99,4,40} & =3.83,
\end{aligned}
$$

the null hypothesis of equal means is rejected only for the Transportation and Public Utilities and Service and Miscellaneous sectors for $\alpha=.05$, and only for the Transportation and Public Utilities sector for $\alpha=.01$. Acceptance of the null hypothesis for the majority of the sectors indicates that mean employment levels for these industries have not varied significantly in the 20-year period. This finding is contrary to the view that dramatic change has occurred in the make-up of nonagricultural employment. However, it is possible that within each geographic division, a shift in jobs between one industry and another has occurred, yet the effect is being lost due to aggregating industries into sectors.

\section{Concluding Remarks}

On the basis of the statistical evidence presented in this note, the major conclusions are:

(1) employment opportunities in the various industrial divisions are not yet homogeneous in all geographic regions, and

(2) there has been no significant change in the sectoral employment make-up in the decades of the 1960s and 1970s.

These findings suggest that the employment shifts of the last two decades may have been more modest than the impression given by the popular press.

\section{REFERENCES}

Hawkins, C. A. and J. E. Weber, Statistical Analysis: Applications to Business and Economics. New York: Harper \& Row, 1980.

Iversen, C. R. and H. Norpoth, Analysis of Variance. Sage Univeraity Paper series on Quantitative Applications in the Social Sciences, series no. 07-001. Beverly Hills and London: Sage Publications, 1976.

\begin{tabular}{|c|c|c|c|c|c|c|c|c|c|}
\hline Contract Construction & 2 & $\begin{array}{l}1 \\
1\end{array}$ & $\begin{array}{l}3 \\
3\end{array}$ & $\begin{array}{l}4 \\
4\end{array}$ & $\begin{array}{l}9 \\
9 \\
9\end{array}$ & $\begin{array}{l}6 \\
6 \\
6\end{array}$ & $\begin{array}{l}5 \\
5\end{array}$ & 8 & \\
\hline Manufacturing & 8 & $\begin{array}{l}7 \\
7\end{array}$ & 4 & $\begin{array}{l}9 \\
9\end{array}$ & $\begin{array}{l}5 \\
5 \\
5\end{array}$ & $\begin{array}{l}\mathbf{2} \\
\mathbf{2} \\
\mathbf{2}\end{array}$ & $\begin{array}{l}6 \\
6\end{array}$ & 1 & 3 \\
\hline $\begin{array}{l}\text { Transportation and } \\
\text { Public Utilities }\end{array}$ & 1 & $\begin{array}{l}6 \\
6\end{array}$ & $\begin{array}{l}3 \\
3 \\
3\end{array}$ & $\begin{array}{l}5 \\
5 \\
5\end{array}$ & $\begin{array}{l}9 \\
9\end{array}$ & $\begin{array}{l}2 \\
2\end{array}$ & $\begin{array}{l}8 \\
8\end{array}$ & 4 & \\
\hline $\begin{array}{l}\text { Wholesale and } \\
\text { Retail Trade }\end{array}$ & 2 & 6 & 1 & $\begin{array}{l}3 \\
3\end{array}$ & $\begin{array}{l}5 \\
5\end{array}$ & $\begin{array}{l}9 \\
9\end{array}$ & 8 & 7 & \\
\hline $\begin{array}{l}\text { Finance, Insurance } \\
\text { and Real Estate }\end{array}$ & 6 & $\begin{array}{l}3 \\
3\end{array}$ & $\begin{array}{l}8 \\
8 \\
8\end{array}$ & $\begin{array}{l}5 \\
5\end{array}$ & $\begin{array}{l}4 \\
4\end{array}$ & $\begin{array}{l}7 \\
7\end{array}$ & 1 & 9 & \\
\hline Service and Miscellaneous & 6 & 3 & 5 & 4 & 9 & 1 & $\begin{array}{l}2 \\
2\end{array}$ & 7 & \\
\hline Government & 1 & 3 & 2 & 4 & 7 & 6 & 9 & 5 & \\
\hline
\end{tabular}

Table 3

Homogenous Subsets of Geographic Regions by Industry Sector 